The Parliamentary Assembly of the Black Sea Economic Cooperation is the BSEC parliamentary dimension. The BSEC Business Council is composed of representatives from the business circles of the member states. The Black Sea Trade and Development Bank is considered as the financial pillar of the BSEC. There is also an International Center for Black Sea Studies and a Coordination Center for the Exchange of Statistical Data and Economic Information.

Headquarters: Sakıp Sabancı Caddesi, Müşir Fuad Paşa Yalısı, Eski Tersane 34460, İstanbul, Turkey.

Website: http://www.bsec-organization.org

Secretary-General: Leonidas Chrysanthopolous (Greece).

\section{Danube Commission}

History and Membership. The Danube Commission was constituted in 1949 according to the Convention regarding the regime of navigation on the Danube signed in Belgrade on 18 Aug. 1948. The Belgrade Convention, amended by the Additional Protocol of 26 March 1998, declares that navigation on the Danube from Kelheim to the Black Sea (with access to the sea through the Sulina arm and the Sulina Canal) is equally free and open to the nationals, merchant shipping and merchandise of all states as to harbour and navigation fees as well as conditions of merchant navigation. The Commission holds annual sessions and is composed of one representative from each of its 11 member countries: Austria, Bulgaria, Croatia, Germany, Hungary, Moldova, Romania, Russia, Serbia, Slovakia and Ukraine.

Functions. To ensure that the provisions of the Belgrade Convention are carried out; to establish a uniform buoying system on all navigable waterways; to establish the basic regulations for navigation on the river and ensure facilities for shipping; to coordinate the regulations for river, customs and sanitation control as well as the hydrometeorological service; to collect relevant statistical data concerning navigation on the Danube; to propose measures for the prevention of pollution of the Danube caused by navigation; and to update its recommendations regularly with a view to bringing them in line with European Union regulations on inland waterway navigation.

Official languages: German, French, Russian.

Headquarters: Benczúr utca 25, H-1068 Budapest, Hungary.

Website: http://www.danubecommission.org

Email: secretariat@danubecom-intern.org

President: Aleksandr Tolkach (Russia).

Director-General: István Valkár (Hungary).

\section{European Trade Union Confederation (ETUC)}

Established in 1973, the ETUC is recognized by the EU, the Council of Europe and EFTA as the only representative crosssectoral trade union organization at a European level. It has grown steadily with a membership of 82 National Trade Union Confederations from 36 countries and 12 European Industry Federations with a total of $60 \mathrm{~m}$. members. The Congress meets every four years; the 11th Statutory Congress took place in Seville in May 2007.
Address: 5 Boulevard Roi Albert II, B-1210 Brussels, Belgium. Website: http://www.etuc.org

Email:etuc@etuc.org

General Secretary: John Monks (UK).

\section{Amnesty International (Al)}

Origin. Founded in 1961 by British lawyer Peter Benenson as a oneyear campaign for the release of prisoners of conscience, Amnesty International has grown to become a worldwide organization, winning the Nobel Peace Prize in 1977.

Activities. AI is a worldwide movement of people campaigning for human rights. It acts independently and impartially to promote respect for internationally recognized human rights standards.

Historically, the focus of AI's campaigning has been: to free all prisoners of conscience (a term coined by Peter Benenson); to ensure a prompt and fair trial for all political prisoners; to abolish the death penalty, torture and other cruel, inhuman or degrading punishments; to end extrajudicial executions and 'disappearances'; to fight impunity by working to ensure perpetrators of such abuses are brought to justice. AI is independent of any government or political ideology, and neither supports nor opposes the views of the victim it seeks to protect.

AI has over $2 \cdot 8 \mathrm{~m}$. members, subscribers and regular donors in more than 150 countries. Major policy decisions are taken by an International Council comprising representatives from all national sections. AI's national sections, members and supporters are primarily responsible for funding the movement. During the financial year 1 April 2007-31 March 2008 AI's total income was $£ 35,224,000$.

Every year AI produces a global report detailing human rights violations in all regions of the world.

International Secretariat: Peter Benenson House, 1 Easton

Street, London WC1X 0DW, UK.

Website: http://www.amnesty.org

Secretary-General (acting): Claudio Cordone (Italy).

\section{Bank for International Settlements (BIS)}

Origin. Founded on 17 May 1930, the Bank for International Settlements fosters international monetary and financial cooperation and serves as a bank for central banks.

Aims. The BIS fulfils its mandate by acting as: a forum to promote discussion and facilitate decision-making processes among central banks and within the international financial community; a centre for economic and monetary research; a prime counterparty for central banks in their financial transactions; and an agent or trustee in connection with international financial operations.

Finance. As of 31 March 2007 some 130 central banks and other official monetary authorities, as well as a number of international institutions, made active use of BIS financial services. Total currency deposits amounted to SDR 222bn., representing around $6 \%$ of world foreign exchange reserves.

Organization and Membership. There are 55 member central banks. These are the central banks or monetary authorities of Algeria, Argentina, Australia, Austria, Belgium, Bosnia and Herzegovina, Brazil, Bulgaria, Canada, Chile, China, Croatia, the Czech Republic, Denmark, Estonia, Finland, France, Germany, Greece, Hong Kong, Hungary, Iceland, India, Indonesia, Ireland, Israel, Italy, Japan, South Korea, Latvia, Lithuania, Macedonia, Malaysia, Mexico, the Netherlands, New Zealand, Norway, Philippines, Poland, Portugal, Romania, Russia, Saudi Arabia, 